\title{
PENGEMBANGAN PROSES BISNIS PENGAWASAN TERINTEGRASI RASIO KONGLOMERASI KEUANGAN STUDI KASUS: INSTANSI X, JAKARTA
}

\section{BUSINESS PROCESS DEVELOMPMENT OF INTEGRATED SUPERVISION OF FINANCIAL CONGLOMERATE RATIO CASE STUDY: INSTITUTION X, JAKARTA}

\author{
Alivia Yulfitri \\ Program Studi Sistem Informasi, Fakultas Ilmu Komputer, Universitas Esa Unggul \\ alivia@esaunggul.ac.id
}

\begin{abstract}
Abstrak - Instansi X memiliki tugas melaksanakan pengawasan terintegrasi Financial Conglomerate Ratio (FICOR) seluruh konglomerasi di Indonesia. FICOR adalah suatu kumpulan data keuangan dan rasio-rasio. Sumber data FICOR adalah data keuangan dari 3 (tiga) sektor pengawasan (Perbankan, Pasar Modal dan IKNB). Saat ini, informasi dan data keuangan konglomerasi keuangan di instansi X, masih tersebar di masing-masing sektor, belum terintegrasi, serta belum terdapat sistem informasi yang membantu pelaksanaan pengawasan terintegrasi. Penelitian ini melakukan analisis proses bisnis pengawasan rasio konglomerasi keuangan yang sedang berjalan, analisis terhadap kondisi infrastruktur IT, dan desain sistem informasi saat ini. Kegiatan ini bertujuan untuk mengembangkan dan memberikan usulan pengembangan proses bisnis saat ini agar dapat melaksanakan visi misi instansi yaitu melaksanakan pengawasan rasio konglomerasi keuangan yang terintegrasi terhadap seluruh perusahaan konglomerasi di Indonesia. Metode yang dilakukan adalah melakukan pengumpulan data melalui waancara dan dokumen internal sebagai referensi untuk melakukan proses analisis, membuat pemetaan proses bisnis yang sedang berjalan serta merancang proses bisnis sesuai dengan yang dibutuhkan. Penelitian ini menghasilkan keluaran berupa usulan perbaikan proses bisnis, yaitu penambahan aktor sebagai pelaku pelaksana proses bisnis, penambahan proses dalam proses bisnis pengawasan terintegrasi, otomatisasi terhadap proses global, proses perhitungan FICOR dan pengecekan data keuangan, serta pengembangan sistem informasi FICOR. Kegiatan ini merupakan tahap awal untuk penelitian selanjutnya yaitu integrasi data dan pengembangan sistem informasi pengawasan terintegrasi rasio konglomerasi keuangan.
\end{abstract}

Kata kunci: proses bisnis, rekayasa ulang proses bisnis, rasio konglomerasi keuangan, FICOR, pengawasan terintegrasi.

\begin{abstract}
Agency X has the task of carrying out an integrated monitoring of the Financial Conglomerate Ratio (FICOR) of all conglomerates in Indonesia. FICOR is a collection of financial data and ratios. FICOR data sources are financial data from 3 (three) supervisory sectors (Banking, Capital Market and IKNB). Currently, financial information and financial conglomerate data in agency X still spread in each sector, not yet integrated, and no information system that helps the implementation of integrated
\end{abstract}

$\begin{array}{ll}\text { Sejarah artikel } & \\ \text { Diterima redaksi: } & : \text { :09 November } 2017 \\ \text { Revisi akhir } & : \text { 15 Desember } 2017 \\ \text { Diterbitkan online } & : \text { 26 Desember } 2017\end{array}$

supervision. This research conducts the business process analysis of the ongoing supervision of financial conglomeration ratio, analysis of IT infrastructure conditions, and the design of the current information system. This activity aims to develop the current business process in order to implement the integrated financial conglomerate ratio control over all conglomerate companies in Indonesia. The method of this research is collecting data through interview and internal documents, analysis process, mapping of as-is business processes, and designing business processes as needed. The output of this research is the proposed business process improvements. The proposed improvement are the addition of actors as executors of business processes, the addition of processes in integrated business supervision process, automation of global processes, FICOR calculation process and financial data checking, and FICOR information system development. Business process development is an early stage for further research that is data integration and information system development of financial conglomeration ratio supervision in the future.

Keywords: business process, business process reengineering, financial conglomerate ratio, integrated supervision.

\section{PENDAHULUAN}

Perusahaan yang selalu berkembang dan ingin mencapai tujuannya dituntut agar proses bisnis dalam perusahaan tersebut pun dapat mengikuti hingga selaras dengan tujuan organisasi. Proses bisnis yang selaras dengan tujuan bisnis organisasi membuat organisasi dapat mencapai tujuan organisasi, lebih bersaing, menyediakan tingkat pelayanan konsumen yang lebih tinggi, memperoleh fleksibilitas lebih besar dalam penggunaan sumber daya, merespon lebih cepat pada peluang baru, serta dapat memanfaatkan teknologi yang lebih baru tanpa hambatan. Oleh sebab itu, selalu diperlukan analisis dan pengembangan proses bisnis agar dapat memenuhi kebutuhan organisasi sesuai dengan tujuan organisasi.

Instansi X merupakan sebuah lembaga pengawas keuangan di Indonesia sebagai tempat studi kasus untuk melakukan pengembangan proses bisnis khususnya pelaporan rasio konglomerasi keuangan. Salah satu tugas dan fungsi instansi X adalah melakukan pengawasan terintegrasi terhadap seluruh 
perusahaan konglomerasi yang ada di Indonesia. Saat ini, tugas dan fungsi tersebut belum dapat dilakukan secara optimal dalam hal pengawasan rasio konglomerasi keuangan secara integrasi, meliputi seluruh sektor keuangan. Hal ini disebabkan oleh pelaporan rasio konglomerasi masih dilakukan secara masing-masing sektor (Perbankan, Pasar Modal, IKNB) kepada instansi X. Padahal satu konglomerasi terdiri dari perusahaan-perusahaan yang mencakup ketiga sektor tersebut, dan membutuhkan perhitungan rasio seluruh sektor sehingga dapat diketahui bagaimana kondisi rasio konglomerasi keuangan secara keseluruhan.

Proses bisnis pengawasan rasio konglomerasi keuangan (FICOR) yang berjalan saat ini, setiap konglomerasi menyerahkan pelaporan FICOR dan data keuangan masih per sektor, secara manual kepada instansi X dan masih dikelola oleh departemen masing-masing sektor (di instansi X) yang belum terintegrasi, dalam database yang terpisah. Hal ini sangat menyulitkan untuk melakukan perhitungan FICOR yang masih dilakukan secara manual sehingga belum dapat dilakukan pengawasan FICOR secara terintegrasi. Disamping itu, belum terdapat sistem informasi FICOR yang terintegrasi. Hal ini menyebabkan instansi $\mathrm{X}$ belum dapat melaksanakan tugas dan fungsinya secara optimal. Oleh sebab itu, sangat dibutuhkan pengembangan proses bisnis rasio konglomerasi keuangan yang terintegrasi, agar perusahaan dapat menjalankan tugas dan fungsinya dengan baik. Pengembangan proses bisnis pelaporan rasio konglomerasi keuangan di instansi X merupakan kegiatan untuk mengetahui proses bisnis saat ini, menganalisis proses bisnis saat ini, serta mengembangkan proses bisnis yang dibutuhkan agar dapat mengakomodir kebutuhan pengawasan rasio konglomerasi keuangan seluruh sektor di Indonesia, yang sudah terintegrasi, di instansi X. Metode pengembangan proses bisnis yang akan dilakukan adalah melakukan proses pengumpulan data mengenai struktur organisasi, proses bisnis, serta sistem informasi, melakukan wawancara lebih dalam, melakukan pemetaan proses bisnis yang sedang berjalan, melakukan analisis masalah yang terjadi pada proses bisnis, serta melakukan perancangan proses bisnis sesuai dengan kebutuhan. Hasil dari kegiatan pengembangan proses bisnis pengawasan terintegrasi rasio konglomerasi keuangan di instansi $\mathrm{X}$ ini merupakan tahap awal untuk melakukan penelitian selanjutnya yaitu integrasi data dan pengembangan sistem informasi pengawasan terintegrasi rasio konglomerasi keuangan.

\section{STUDI LITERATUR}

\section{A. Lembaga Jasa Keuangan (LJK)}

Berdasarkan Peraturan Otoritas Jasa Keuangan Nomor 18/POJK.03/2014 tentang Penerapan Tata Kelola Terintegrasi Bagi Konglomerasi Keuangan [7], Lembaga Jasa Keuangan yang selanjutnya disebut LJK adalah lembaga yang melaksanakan kegiatan di sektor perbankan, pasar modal, perasuransian, dana pensiun, lembaga pembiayaan, dan Lembaga Jasa Keuangan lainnya sebagaimana dimaksud dalam Undang-Undang mengenai Otoritas Jasa Keuangan. Grup LJK adalah dua atau lebih LJK yang berada dalam satu grup atau kelompok karena keterkaitan kepemilikan dan/atau pengendalian. Jenis LJK yang termasuk dalam cakupan Konglomerasi Keuangan adalah bank, perusahaan asuransi dan reasuransi, efek, dan perusahaan pembiayaan.

\section{B. Konglomerasi Keuangan}

Sesuai POJK No. 17/POJK.O3/2014 [6] tentang Penerapan Manajemen Risiko Terintegrasi terhadap Konglomerasi Keuangan, LJK yang berada dalam satu grup atau kelompok karena keterkaitan kepemilikan dan/atau pengendalian, dianggap sebagai Konglomerasi Keuangan (KK).

Berdasarkan Rancangan Peraturan Otoritas Jasa Keuangan tentang Perusahaan Induk Konglomerasi Keuangan tahun 2017 [8], Konglomerasi Keuangan adalah Grup LJK yang melakukan kegiatan usaha jasa keuangan yang signifikan dan paling sedikit pada dua sektor atau jenis usaha yang berbeda yaitu perbankan, pasar modal, perasuransian, lembaga pembiayaan, dan/atau Lembaga Jasa Keuangan lainnya.

Menurut informasi dari kompas.com [10], hingga tahun 2014, OJK telah mengidentifikasi 31 konglomerasi keuangan. Dari jumlah tersebut, 10 di antaranya berbentuk vertical group, atau memiliki hubungan langsung antara perusahaan induk dan perusahaan anak. Baik induk maupun anak perusahaan keduanya termasuk LJK. Selain itu, 13 di antaranya berbentuk horizontal group atau tidak terdapat hubungan langsung antara LJK yang berada dalam satu konglomerasi keuangan. LJK tersebut dimiliki atau dikendalikan pihak yang sama. Sementara itu, delapan di antaranya adalah mixed group atau percampuran keduanya. Berdasarkan temuan OJK, 31 konglomerasi keuangan tersebut menguasai hampir 70 persen total aset sektor keuangan di Indonesia. Hingga semester I-2014, total aset sektor keuangan berjumlah Rp 5.400 triliun.

Sementara berdasarkan Detik.com [9] dan Metrotvnews.com [11], Jakarta, Otoritas Jasa Keuangan (OJK) akan menerbitkan peraturan OJK (POJK) tentang Perusahaan Induk Konglomerasi Keuangan (PIKK). Dalam rancangan POJK tersebut, suatu grup lembaga jasa keuangan baru dinyatakan sebagai suatu konglomerasi keuangan apabila terdapat lembaga jasa keuangan setidaknya dua sektor yaitu bank, perusahaan asuransi dan reasuransi, perusahaan efek, dan atau perusahaan pembiayaan, dan konglomerasi keuangan tersebut memiliki total aset minimal Rp2 triliun. Berdasarkan kriteria baru tersebut, saat ini terdapat 48 konglomerasi keuangan dengan total aset per posisi 31 Desember 2016 mencapai Rp 5.915 triliun atau 67,52 persen dari total aset keseluruhan sektor jasa keuangan. Untuk POJK sendiri ditargetkan akan terbit sebelum akhir 2017.

\section{Rasio Keuangan}

Menurut James C Van Horne dikutip dari Kasmir [5], definisi Rasio keuangan merupakan indeks yang menghubungkan 2 (dua) angka akuntansi dan diperoleh dengan membagi satu angka dengan angka lainnya. Rasio keuangan adalah alat yang digunakan untuk menganalisis kondisi keuangan dan kinerja perusahaan. Kita menghitung berbagai rasio karena dengan cara ini kita bisa mendapat perbandingan yang mungkin akan berguna daripada berbagai angka mentahnya sendiri. Salah satu metode yang dapat dilakukan untuk menganalisa laporan keuangan adalah analisis rasio. Analisis rasio adalah cara analisa dengan menggunakan perhitungan-perhitungan perbandingan atas data kuantitatif yang ditujukkan dalam neraca maupun laba rugi. Pada dasarnya perhitungan rasio-rasio keungan adalah untuk menilai kinerja keuangan perusahaan di masa lalu, saat ini, dan kemungkinannya di masa depan. Menurut Irawati [4], rasio keuangan merupakan teknik analisis dalam bidang manajemen keuangan yang dimanfaatkan sebagai alat ukur kondisi keuangan 
suatu perusahaan dalam periode tertentu, ataupun hasil-hasil usaha dari suatau perusahaan pada satu periode tertentu dengan jalan membandingkan dua buah variabel yang diambil dari laporan keuangan perusahaan, baik daftar neraca maupun laba rugi.

Financial Conglomerate Ratio (FICOR) atau rasio konglomerasi keuangan adalah suatu kumpulan data keuangan dan rasio-rasio untuk membantu Pengawas Terintegrasi dalam melakukan penilaian atas kondisi suatu konglomerasi keuangan berdasarkan data dan informasi keuangan dari grup konglomerasi keuangan, rasio komparatif dan trend analysis. Sumber data FICOR adalah data keuangan yang terdapat pada 3 (tiga) sektor pengawasan yaitu perbankan, pasar modal dan Industri Keuangan Non Bank (IKNB).

\section{Laporan Keuangan}

Dalam pengertian yang sederhana, laporan keuangan adalah laporan yang menunjukkan kondisi keuangan perusahaan pada saat ini atau dalam periode tertentu, laporan keuangan menggambarkan kondisi keuangan perusahaan pada suatu periode. Menurut Kasmir [5] secara umum, pengertian laporan keuangan adalah laporan yang menunjukkan kondisi keuangan perusahaan pada suatu periode tertentu. Menurut Harahap [3] menyatakan bahwa "Laporan keuangan menggambarkan kondisi keuangan dan hasil usaha suatu perusahaan pada saat tertentu atau jangka waktu tertentu. Adapun jenis laporan keuangan yang lazim dikenal adalah neraca, laporan laba rugi, laporan arus kas dan laporan perubahan posisi keuangan”.

\section{E. Proses Bisnis}

Definisi proses bisnis menurut Buttler Group [1] adalah " $A$ business process as a series of tasks or activities to achieve a given purpose or goal, which can be completed either in sequence or in parallel, by people or systems, either inside or outside an organization." Proses bisnis adalah sekumpulan tugas atau aktivitas untuk mencapai maksud dan tujuan yang diinginkan, yang dikerjakan secara sekuensial atau paralel, oleh manusia atau sistem, baik di dalam maupun di luar organisasi. Tahapan proses bisnis yang dilakukan adalah seperti yang dijelaskan pada Gambar 1 .

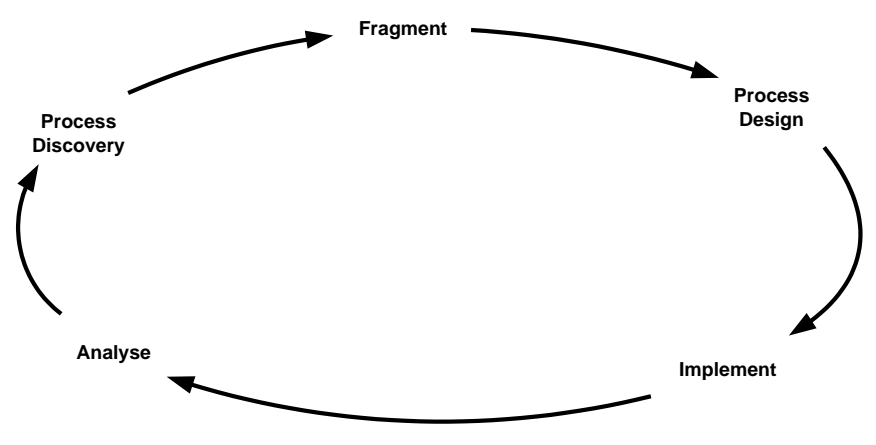

Gambar 1 Tahapan proses bisnis

\section{Proses Penemuan (Discovery Process)}

Tahap pertama adalah menemukan kejadian yang sesungguhnya pada satu cakupan yang lebih luas; dalam kata lain untuk mendefinisikan proses-proses tingkat tinggi dengan organisasinya.

\section{2. $\quad$ Proses Fragmentasi (Fragment)}

Tahap kedua yaitu memecah proses menjadi komponenkomponen sub-proses atau aktifitas/kejadian, dan menemukan aturan yang ada di dalam proses tersebut untuk menyatukannya kembali.

3. Proses Desain (Design Process)

Tahap ketiga ini adalah tahap mendesain proses yang berjalan dan dibutuhkan.

4. Proses Implementasi

Tahap ini menentukan mana aplikasi-aplikasi yang relevan diambil pada waktu yang tepat, dan tampilan alur kerja/workflow dapat dikenali untuk meyakinkan orang yang terlibat pada saat dibutuhkan.

5. Proses Analisis/ Pemeliharaan / Pengawasan

Tahap ini adalah adalah tahap umpan balik ketika proses bisnis tersebut sudah dijalankan.

Dari lima tahapan di atas, peneliti akan melakukan hingga tahap ketiga, yaitu hingga mendapatkan proses bisnis yang dibutuhkan.

\section{F. Pemetaan Proses Bisnis}

Tahap pemetaan proses bisnis adalah menggambarkan proses bisnis saat ini ke dalam gambar dengan metodologi tertentu, agar analis bisnis dapat mengkomunikasikan hasil temuan analis bisnis kepada pihak lain yang terkait. Tahap ini bertujuan untuk mendapatkan pengertian lengkap tentang proses agar dapat menjelaskan karakteristik dan tujuan sehingga semua orang di dalam proses tersebut dapat melihat misi yang sama dan mempunyai satu dasar berpijak yang sama ketika akan menjalankan proses tersebut. Metodologi yang digunakan untuk melakukan pemetaan proses bisnis adalah berdasarkan tahapan proses bisnis dari Buttler Group, sebagai berikut :

a. Identifikasi proses bisnis: Identifikasi proses bisnis yaitu mendefinisikan proses-proses tingkat tinggi

b. Menggambarkan proses bisnis: Tujuan pada tahap ini adalah untuk memperoleh satu pengertian yang lengkap tentang proses agar dapat memperjelas karakteristik dan tujuannya sehingga semua orang yang terlibat didalamnya melihat dengan visi yang sama, dan memiliki satu dasar untuk berpijak ketika memperbaiki proses tersebut.

c. Identifikasi Komponen: Identifikasi dapat dilakukan dengan mengajukan pertanyaan: who, what, why, where, when dan how.

d. Tahap Pemahaman: pada tahap ini proses bisnis, langkah yang perlu dilakukan adalah membuat skup dan batasanbatasan, membuat pemetaan proses bisnis yang sedang berjalan.

G. Desain Proses Bisnis yang Diinginkan

Dalam tahap desain ini, peneliti menganalisis proses bisnis dengan melakukan perbaikan dengan menggunakan cara ESIA, yaitu:

a. Eliminate (eliminasi proses): menghilangkan proses yang dinilai tidak dibutuhkan atau tidak efektif dilakukan.

b. Simplify (sederhanakan proses): menganalisis apakah terdapat proses yang masih dapat disederhanakan atau dibantu/digantikan oleh teknologi sistem informasi 
sehingga dapat mempersingkat waktu/lamanya proses tanpa menghilangkan tujuan yang akan dicapai.

c. Integrate (integrasi proses): menganalisis apakah terdapat proses yang masih dapat digabungkan menjadi satu proses.

d. Automate (otomatisasi proses): Proses yang sedang berjalan apakah sudah didukung oleh teknologi sistem informasi atau belum. Jika belum, lebih baik dirancang sistem informasi untuk mendukung proses bisnis.

\section{METODOLOGI PENELITIAN}

Tahapan penelitian yang dilakukan adalah sebagai berikut dimana tahapan yang dilakukan dalam penelitian ini adalah seperti yang ditunjukan dalam gambar 2.

1. Melakukan proses pengumpulan data melalui dokumen internal sebagai referensi untuk melakukan proses asesmen sesuai daftar dokumen kebutuhan (strategi perusahaan, struktur organisasi, proses bisnis, dan desain sistem informasi)

2. Melakukan wawancara yang lebih mendalam

3. Melakukan pemetaan proses bisnis yang sedang berjalan.

4. Melakukan analisis masalah yang terjadi.

5. Melakukan perancangan proses bisnis sesuai dengan yang dibutuhkan.

Penelitian diawali dengan melakukan proses pengumpulan data melalui dokumen internal sebagai referensi untuk menganalisis permasalahan kondisi perusahaan saat ini. Tahap yang kedua adalah memetakan proses bisnis yang sedang berjalan saat ini. Tahap ketiga adalah analisis masalah yang terjadi, menganalisis kondisi saat ini dan kebutuhan perusahaan di masa mendatang untuk mendapatkan identifikasi kebutuhan pengembangan yang harus dilakukan. Dan tahap terakhir adalah melakukan pengembangan proses bisnis yang dibutuhkan sesuai dengan tujuan perusahaan yaitu terintegrasinya pengawasan rasio konglomerasi.

\section{HASIL DAN ANALISIS}

A. Hasil Analisis Proses Bisnis Saat ini

Dalam proses ini terdapat tiga peran, yaitu:

a. Konglomerasi Keuangan: menyerahkan laporan FICOR dan data keuangan;

b. Staf dan kasubbag: yang bertugas menjalakan pengawasan terintegrasi sesuai tugasnya;

c. Kepala Bagian dan direktur: yang bertugas menjalakan tugas pengawasan terintegrasi sesuai tugasnya.

Alur proses bisnis yang berjalan saat ini pada proses pengawasan terintegrasi laporan rasio konglomerasi keuangan adalah sebagai berikut:

a. Konglomerasi keuangan menyerahkan laporan laporan risiko terintegrasi secara semesteran untuk posisi Juni dan Desember, dalam bentuk dokumen (laporan profil resiko terintegrasi) kepada pengawas terintegrasi, dengan syarat waktu sebagai berikut: 1) Laporan risiko terintegrasi disampaikan paling lambat pada tanggal 15 (lima belas) bulan kedua setelah berakhirnya bulan laporan yang bersangkutan; dan 2) Laporan data keuangan disampaikan paling lambat tanggal 20 (dua puluh) setiap bulan

b. Staf Pengawas terintegrasi memeriksa laporan yang diserahkan dengan melakukan perhitungan secara manual setiap profil risiko.

c. Kepala sub bagian dan staf Pengawas terintegrasi mengoreksi laporan yang diserahkan secara manual dengan memeriksa laporan data keuangan secara manual sebagai data pendukung.

d. Direktur departemen dan Kepala Bagian Pengawas terintegrasi melakukan approval secara manual untuk laporan yang sudah dikoreksi.

Dalam proses bisnis ini, seluruh proses pengawasan terintegrasi FICOR masih dilakukan secara manual, dimana tidak memungkinkan untuk dilakukan perhitungan rasio konglomerasi keuangan yang terintegrasi. Hal ini mengakibatkan belum dapat dilakukan pengawasan yang terintegrasi terhadap seluruh konglomerasi di Indonesia. Di samping itu, perhitungan rasio konglomerasi yang terintegrasi antara ketiga sektor mengalami kesulitan karena belum memiliki sistem informasi rasio konglomerasi keuangan (FICOR) yang terintegrasi. Agar lebih jelas, proses bisnis yang sudah dijelskan digambarkan dalam flowmap pada Gambar 3. Analisis dilakukan terhadap beberapa aspek, yaitu analisis strategi, struktur organisasi, proses bisnis, sistem informasi, dan data. Hasil analisis diperoleh kesimpulan bahwa terjadi permasalahan sebagai berikut:

a. Pengawasan rasio konglomerasi keuangan saat ini masih dilakukan pada masing-masing sektor, belum dapat dilakukan pengawasan terintegrasi;

b. Belum terdapat proses bisnis pengawasan rasio konglomerasi keuangan yang mendukung pelaksanaan pengawasan rasio konglomerasi keuangan secara terintegrasi, belum terdapat integrasi data dan belum terdapat pelaporan yang terintegrasi seluruh sektor secara otomatis;

c. Belum terdapat sistem informasi pelaporan FICOR yang terintegrasi sehingga mendukung pelaksanaan pengawasan terintegrasi seluruh sektor;

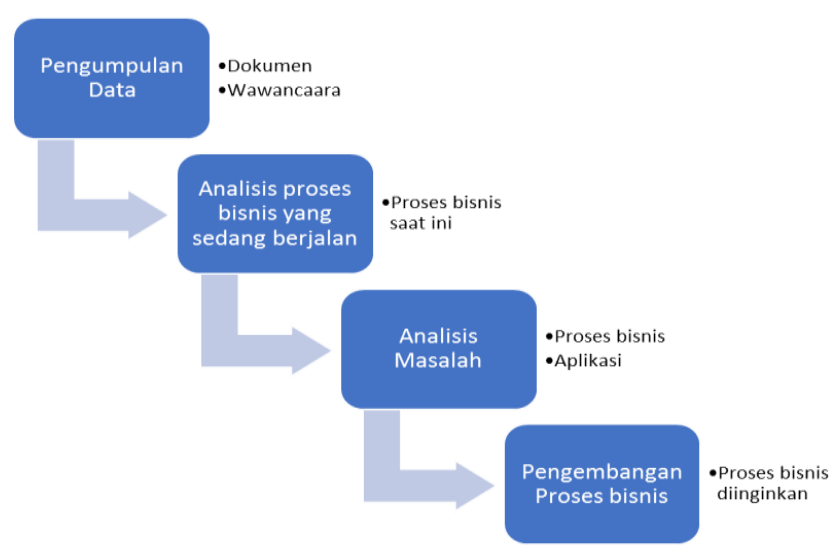

Gambar 2 Metodologi penelitian 


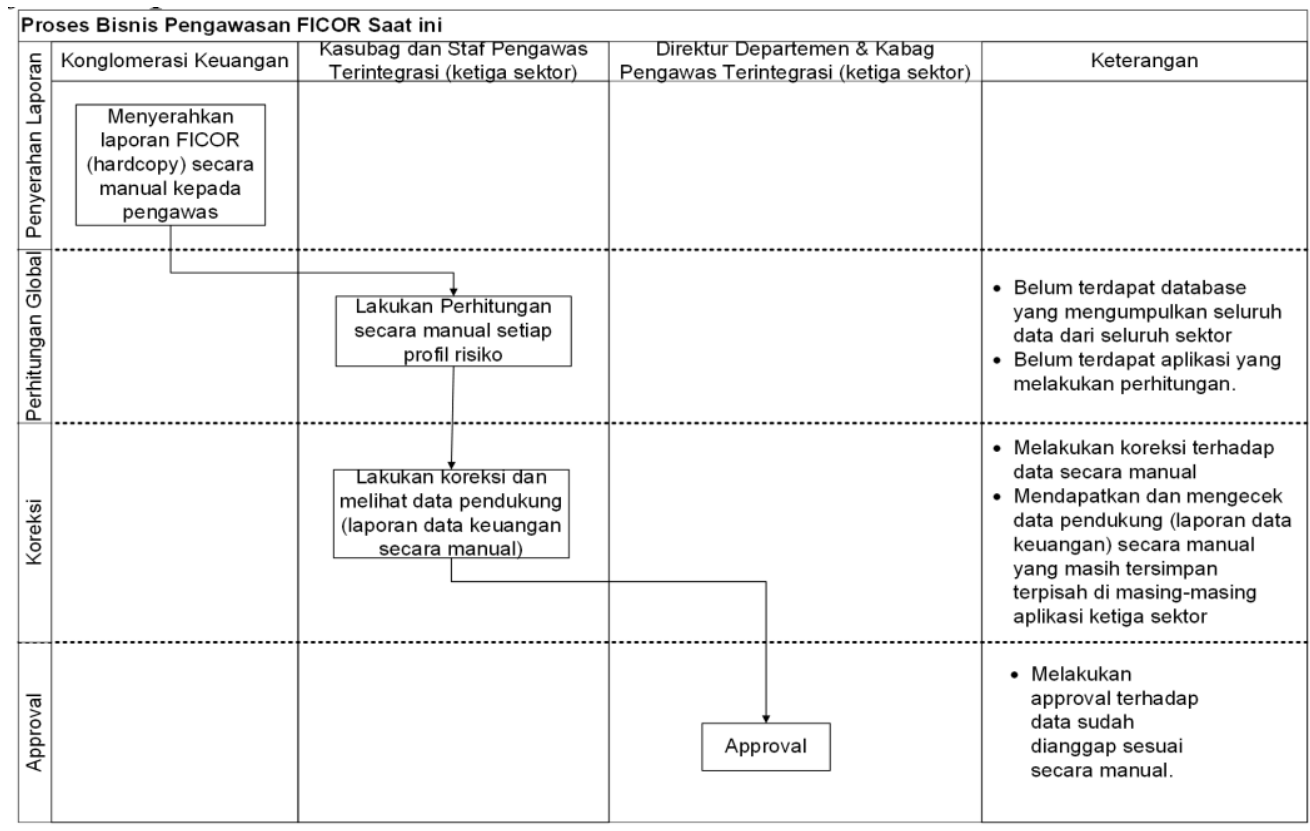

Gambar 3 Proses Bisnis Pengawasan FICOR saat ini

Data seluruh sektor masih disimpan di masing-masing sektor. Hal ini menjadi kendala pengawas untuk mendapatkan data dukung secara terintegrasi seperti laporan data keuangan masing-masing konglomerasi keuangan sebagai bagian dari pelaksanaan tugas pengawasan. Berdasarkan hasil analisis data dan sistem informasi saat ini, didapatkan desain aliran data dan sistem informasi seperti dijelaskan dalam Gambar 4. Berdasarkan Gambar 4, dapat dilihat bahwa data dan sistem informasi masing-masing sektor masih berdiri sendiri, belum terintegrasi, sehingga dibutuhkan pengembangan proses bisnis yang dapat mendukung pelaksanaan pengawasan secara terintegrasi pada rasio konglomerasi keuangan. Target utama penelitian ini adalah merancang usulan proses bisnis yang mendukung pelaksanaan pelaporan dan pengawasan rasio konglomerasi keuangan yang terintegrasi.

\section{B. Usulan Pengembangan Proses Bisnis}

Usulan pengembangan proses bisnis dapat dilihat secara rinci pada Tabel I. Perancangan perbaikan proses bisnis menggunakan cara ESIA, yaitu dengan melakukan eliminate (eliminasi proses), simplify (sederhanakan proses), integrate (integrasikan proses), dan automate (otomatisasi proses). Berdasarkan hasil analisis permasalahan di atas, secara garis besar dapat diusulkan sebagai berikut:

a. Eliminate (eliminasi proses): Dari pemetaan proses bisnis saat ini tidak terdapat proses yang dapat dihilangkan, sehingga sehingga tidak ada yang perlu dieliminasi.

b. Simplify (sederhanakan proses): Dari proses yang sedang berjalan, diusulkan agar dapat menggunakan sistem informasi yang terintegrasi agar dapat menyederhanakan berbagai proses sebagai berikut: 1) Proses perhitungan rasio FICOR; dan 2) Proses melihat data pendukung: laporan data keuangan yang masih tersebar di masingmasing aplikasi ketiga sektor.

c. Integrate (penggabungan proses): dalam proses ini tidak terdapat proses yang dapat digabung.

d. Automate (otomatisasi): Proses yang sedang berjalan belum memiliki pengolahan data yang terkomputerisasi. Sistem informasi FICOR sebaiknya dirancang agar proses dapat dilakukan secara otomatis dan berjalan lebih cepat.

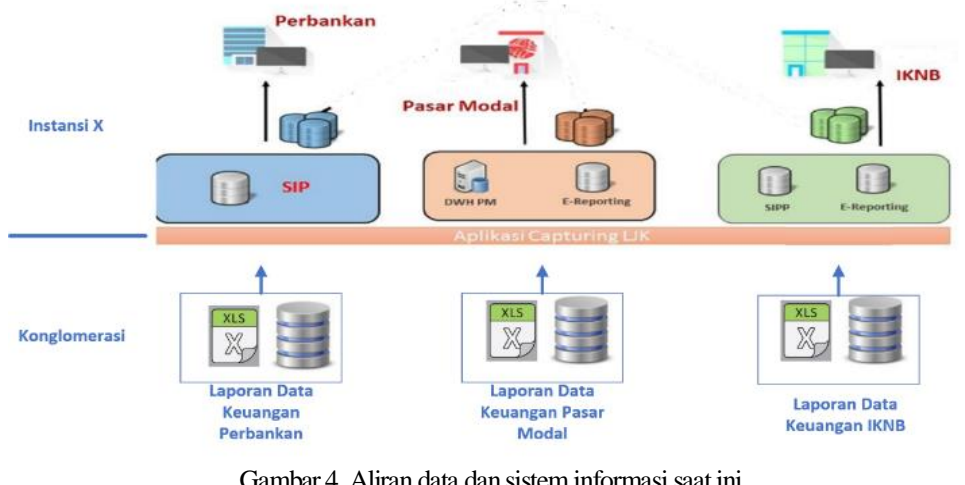

Pengembangan Proses Bisnis Pengawasan Terintegrasi Rasio Konglomerasi Keuangan Studi Kasus: Instansi X, Jakarta 
TABELI

USULAN PENGEMBANGAN PROSES BISNI

\begin{tabular}{|c|c|c|c|}
\hline $\begin{array}{c}\text { No } \\
\text { Proses } \\
\end{array}$ & $\begin{array}{c}\text { Proses bisnis } \\
\text { saat ini }\end{array}$ & $\begin{array}{c}\text { Proses bisnis yang } \\
\text { diusulkan }\end{array}$ & Keterangan \\
\hline 1 & $\begin{array}{l}\text { Konglomerasi } \\
\text { keuangan } \\
\text { menyerahkan } \\
\text { laporan laporan } \\
\text { risiko } \\
\text { terintegrasi } \\
\text { secara } \\
\text { semesteran untuk } \\
\text { posisi Juni dan } \\
\text { Desember, } \\
\text { dalam bentuk } \\
\text { dokumen kepada } \\
\text { pengawas } \\
\text { terintegrasi }\end{array}$ & 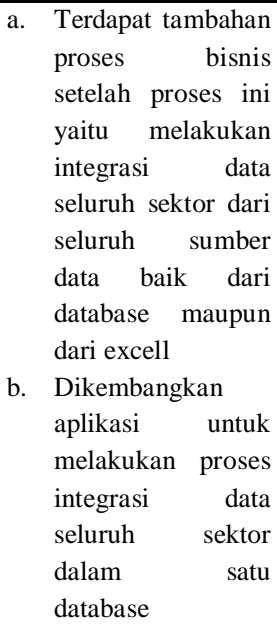 & \\
\hline 2 & $\begin{array}{l}\text { Staf Pengawas } \\
\text { terintegrasi } \\
\text { memeriksa } \\
\text { laporan yang } \\
\text { diserahkan } \\
\text { dengan } \\
\text { melakukan } \\
\text { perhitungan } \\
\text { secara manual } \\
\text { setiap profil } \\
\text { risiko }\end{array}$ & $\begin{array}{l}\text { Dikembangkan } \\
\text { aplikasi perhitungan } \\
\text { profil risiko dengan } \\
\text { data yang sudah } \\
\text { terintegrasi seluruh } \\
\text { sektor }\end{array}$ & $\begin{array}{l}\text { Staf } \\
\text { pengawas } \\
\text { terintegrasi } \\
\text { tidak perlu } \\
\text { melakukan } \\
\text { perhitungan } \\
\text { manual } \\
\text { karena } \\
\text { dibuatkan } \\
\text { otomatis } \\
\text { oleh sistem } \\
\text { informasi }\end{array}$ \\
\hline 3 & $\begin{array}{l}\text { Kepala sub } \\
\text { bagian dan staf } \\
\text { Pengawas } \\
\text { terintegrasi } \\
\text { mengoreksi } \\
\text { laporan yang } \\
\text { diserahkan } \\
\text { secara manual } \\
\text { dengan } \\
\text { memeriksa } \\
\text { laporan data } \\
\text { keuangan secara } \\
\text { manual sebagai } \\
\text { data pendukung. }\end{array}$ & \begin{tabular}{lr} 
1. & \multicolumn{2}{l}{ Dikembangkan } \\
aplikasi koreksi \\
laporan dengan \\
data yang sudah \\
terintegrasi & seluruh \\
sektor & \\
2. Dikembangkan & aplikasi melihat \\
data dukung \\
(laporan data \\
keuangan) dengan \\
data yang sudah \\
terintegrasi seluruh \\
sektor
\end{tabular} & $\begin{array}{l}\text { Kepala sub } \\
\text { bagian dan } \\
\text { staf } \\
\text { pengawas } \\
\text { terintegrasi } \\
\text { dapat } \\
\text { mengoreksi } \\
\text { laporan di } \\
\text { system } \\
\text { informasi } \\
\text { dan dapat } \\
\text { langsung } \\
\text { melihat data } \\
\text { pendukung } \\
\text { lewat sistem } \\
\text { informasi. }\end{array}$ \\
\hline 4 & $\begin{array}{l}\text { Direktur } \\
\text { departemen dan } \\
\text { Kepala Bagian } \\
\text { Pengawas } \\
\text { terintegrasi } \\
\text { melakukan } \\
\text { approval secara } \\
\text { manual untuk } \\
\text { laporan yang } \\
\text { sudah dikoreksi. }\end{array}$ & $\begin{array}{l}\text { Dikembangkan } \\
\text { aplikasi approval } \\
\text { dengan data yang } \\
\text { sudah terintegrasi } \\
\text { seluruh sektor }\end{array}$ & \\
\hline
\end{tabular}

Berdasarkan tabel I tersebut, dapat didetilkan kembali proses bisnis yang diusulkan untuk melakukan pengawasan terintegrasi rasio konglomerasi keuangan, mencakup proses seperti yang ditampilkan pada Tabel II.

TABEL II

SPESIFIKASIPROSES

\begin{tabular}{|c|c|c|}
\hline No & $\begin{array}{l}\text { Nama } \\
\text { Proses }\end{array}$ & Aktor \\
\hline 1. & Posting Data & $\begin{array}{l}\text { Hanya dapat dilakukan oleh user IT } \\
\text { seagai administrator }\end{array}$ \\
\hline 2. & Upload Data & $\begin{array}{l}\text { Hanya dapat dilakukan oleh user IT } \\
\text { seagai administrator }\end{array}$ \\
\hline 3. & $\begin{array}{l}\text { Proses } \\
\text { Global }\end{array}$ & $\begin{array}{l}\text { Hanya dapat dilakukan oleh user IT } \\
\text { seagai administrator }\end{array}$ \\
\hline 4. & Koreksi Data & $\begin{array}{l}\text { Dilakukan oleh kepala sub bagian dan } \\
\text { staf pengawas }\end{array}$ \\
\hline 5. & $\begin{array}{l}\text { Approval } \\
\text { Data }\end{array}$ & $\begin{array}{l}\text { Dilakukan oleh direktur dan kepala } \\
\text { bagian }\end{array}$ \\
\hline
\end{tabular}

Usulan rancangan proses bisnis di atas terdapat beberapa tambahan proses yang harus dilakukan oleh IT untuk melakukan proses posting data, upload data, dan proses global. Oleh sebab itu, diperlukan tambahan satu peran yaitu IT sebagai pengelola data. Sehingga dalam proses bisnis yang diusulkan terlibat empat peran, sebagai berikut:

a. Konglomerasi Keuangan: berkewajiban menyerahkan laporan FICOR dan data keuangan pada instansi X;

b. IT : bertugas mengelola data dan system;

c. Staf dan kasubbag: bertugas melaksanakan pengawasan terintegrasi sesuai tugasnya;

d. Kepala Bagian dan direktur: bertugas melaksanakan tugas pengawasan terintegrasi sesuai tugasnya.

Secara keseluruhan rancangan proses bisnis yang diusulkan sebagai pengembangan proses bisnis pengawasan rasio konglomerasi keuangan yang terintegrasi dan terotomatisasi. Selain itu, usulan desain integrasi data dan sistem informasi seperti ditampilkan pada Gambar 5.

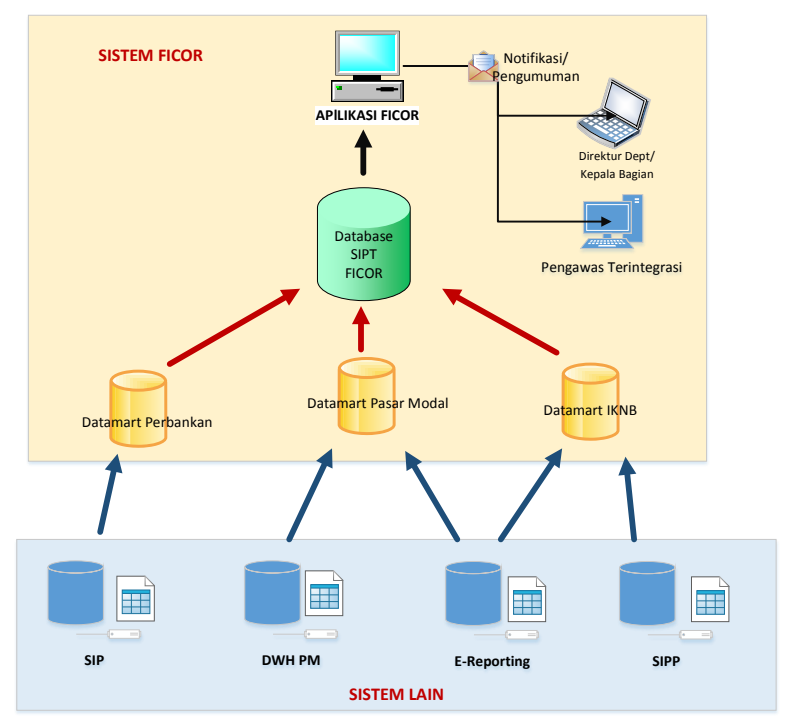

Gambar 5 Usulan Pengembangan Proses Bisnis 
Gambar 5 menjelaskan mengenai usulan proses pengintegrasian data yang dimulai dari pengambilan data yang masih tersimpan di setiap sektor berbeda, disatukan menjadi satu datamart. Dimana datamart tersebut yang akan diakses untuk pengembangan aplikasi FICOR sebagai aplikasi yang mendukung pelaksanaan proses bisnis pelaporan FICOR sebagai perwujudan tugas dari pengawasan terintegrasi. Rancangan proses bisnis yang diusulkan sebagai pengembangan proses bisnis pengawasan rasio konglomerasi keuangan yang terintegrasi dan terotomatisasi dapat dilihat pada gambar 6. Selain itu, aliran proses lebih detil dari usulan proses yang diusulkan, mulai dari posting data hingga approval dapat dilihat pada gambar 7 hingga gambar 12 .

\section{KESIMPULAN}

Proses bisnis pengawasan rasio konglomerasi keuangan (FICOR) yang berjalan saat ini, setiap konglomerasi menyerahkan pelaporan FICOR dan data keuangan masih per sektor, secara manual kepada instansi $\mathrm{X}$ dan masih dikelola oleh departemen masing-masing sektor (di instansi $\mathrm{X}$ ) yang belum terintegrasi, dalam database yang terpisah, perhitungan FICOR masih dilakukan secara manual dan belum dapat dilakukan pengawasan laporan FICOR secara terintegrasi. Saat ini pun belum terdapat sistem informasi FICOR yang terintegrasi. Dan belum terdapat proses bisnis yang mengakomodir kebutuhan pelaksanaan pengawasan rasio konglomerasi keuangan yang terintegrasi. Hal ini mengakibatkan instansi $\mathrm{X}$ belum dapat menjalankan tugasnya sebagai pengawas terintegrasi terhadap seluruh konglomerasi di Indonesia secara optimal.

Berdasarkan permasalahan di atas, maka perlu dilakukan perbaikan proses bisnis pengawasan FICOR yang berjalan saat ini agar dapat melaksanakan tugas pengawasan terintegrasi. Perbaikan proses bisnis yang diusulkan adalah penambahan aktor yang terlibat dalam proses bisnis pengawasan FICOR, perubahan proses bisnis yang dibutuhkan, serta pengembangan sistem informasi yang terintegrasi dalam hal mekanisme penyerahan laporan FICOR seluruh konglomerasi, mengintegrasikan data FICOR, data keuangan, perhitungan FICOR dan pengecekan data pendukung secara terintegrasi.

Adapun perubahan proses bisnis yang dibutuhkan adalah penambahan proses untuk posting data keuangan dan FICOR dari seluruh konglomerasi di Indonesia yang sudah terintegrasi, upload data keuangan dan FICOR yang sudah terintegrasi, menjalankan proses global untuk melakukan perhitungan FICOR otomatis, koreksi data secara online dengan data pendukung yang terintegrasi, yang dilakukan oleh pengawas terintegrasi dan proses approval data oleh para pejabat pengawas terintegrasi. Dimana seluruh proses bisnis usulan tersebut akan dikembangkan menjadi proses yang dilakukan secara otomatis dan dibuat dalam sebuah sistem informasi FICOR yang terintegrasi untuk seluruh sektor perbankan dan jasa keuangan. Keluaran penelitian ini adalah berupa rancangan usulan proses bisnis yang mendukung pelaksanaan pengawasan terintegrasi sesuai dengan visi misi instansi.

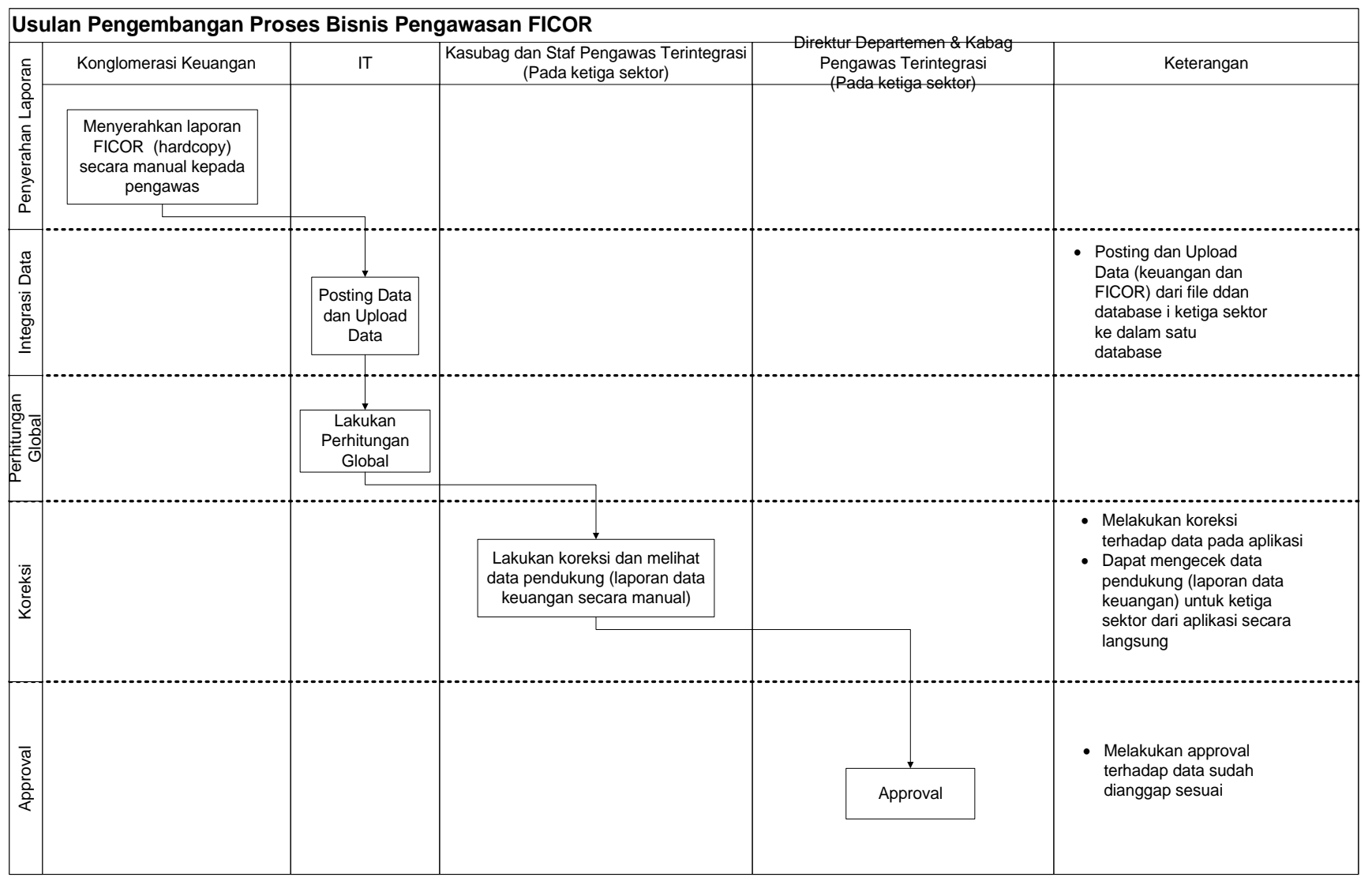

Gambar 5 Usulan Pengembangan Proses Bisnis 
DOI: https://doi.org/10.25124/jrsi.v4i02.282

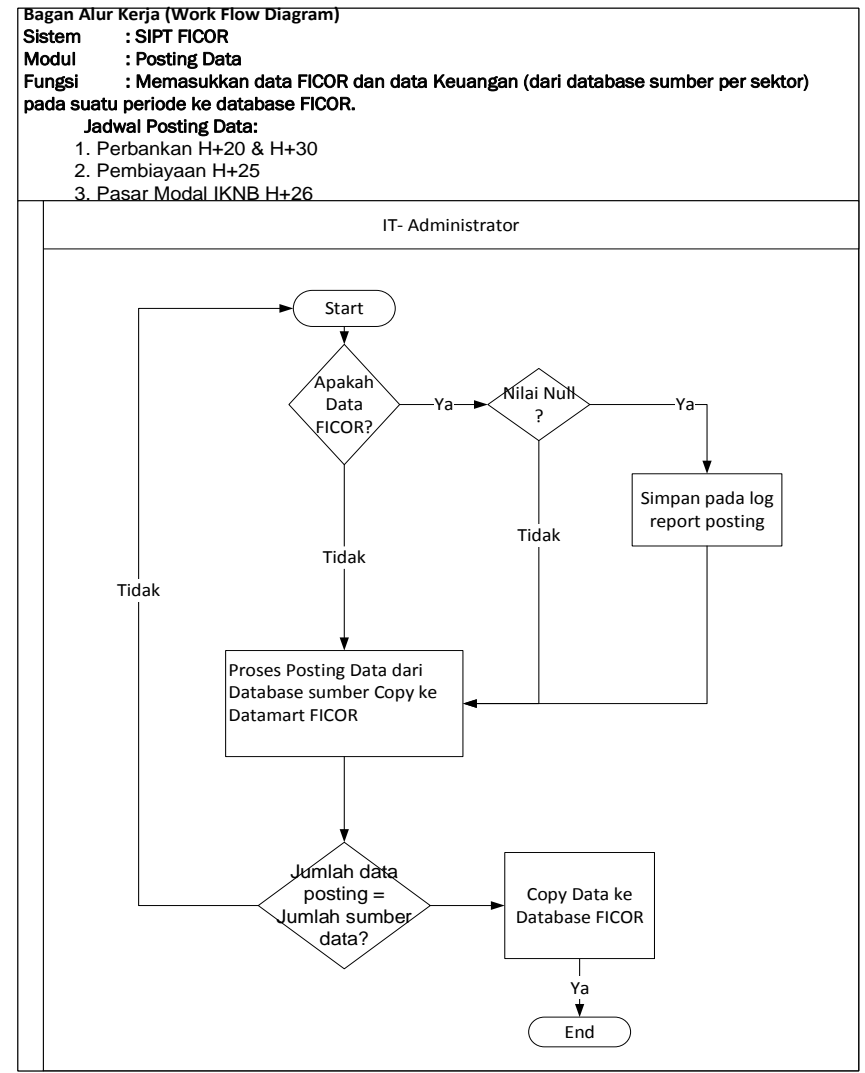

Gambar 7 Bagan Alur Kerja Posting Data

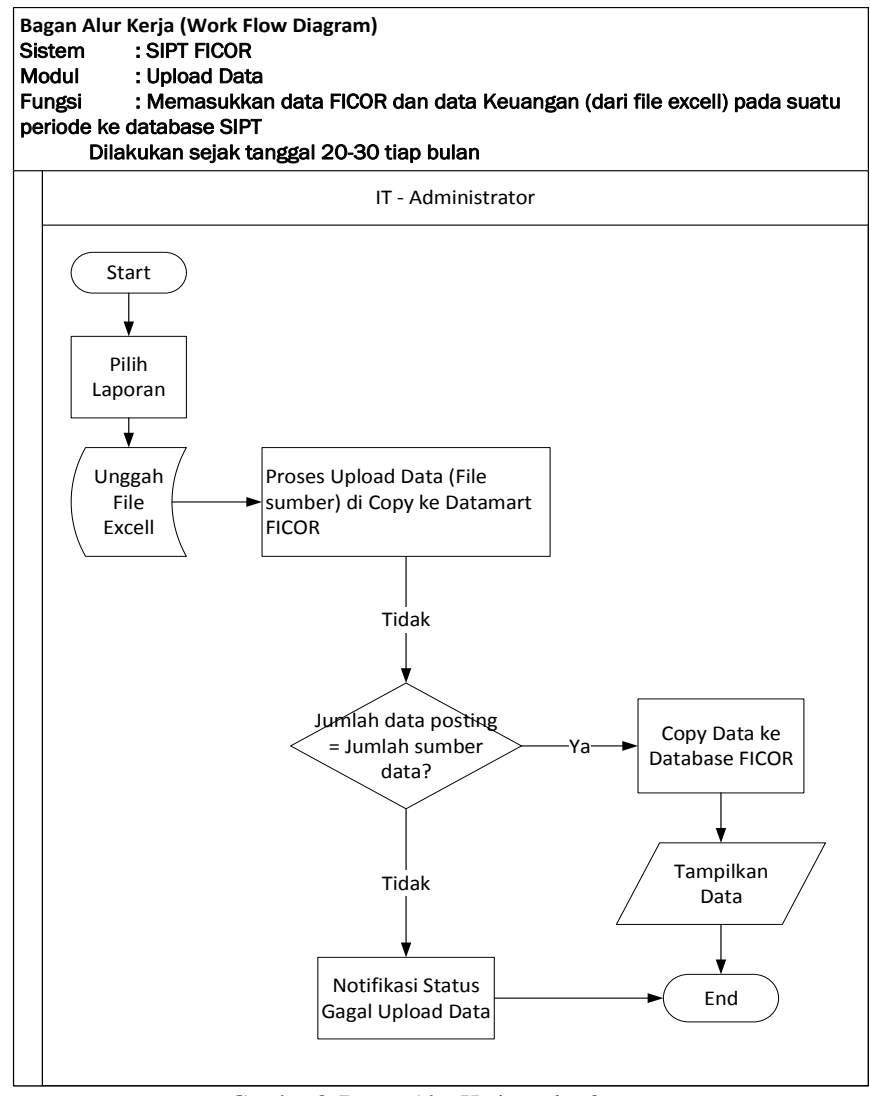

Gambar 8 Bagan Alur Kerja Upload Data

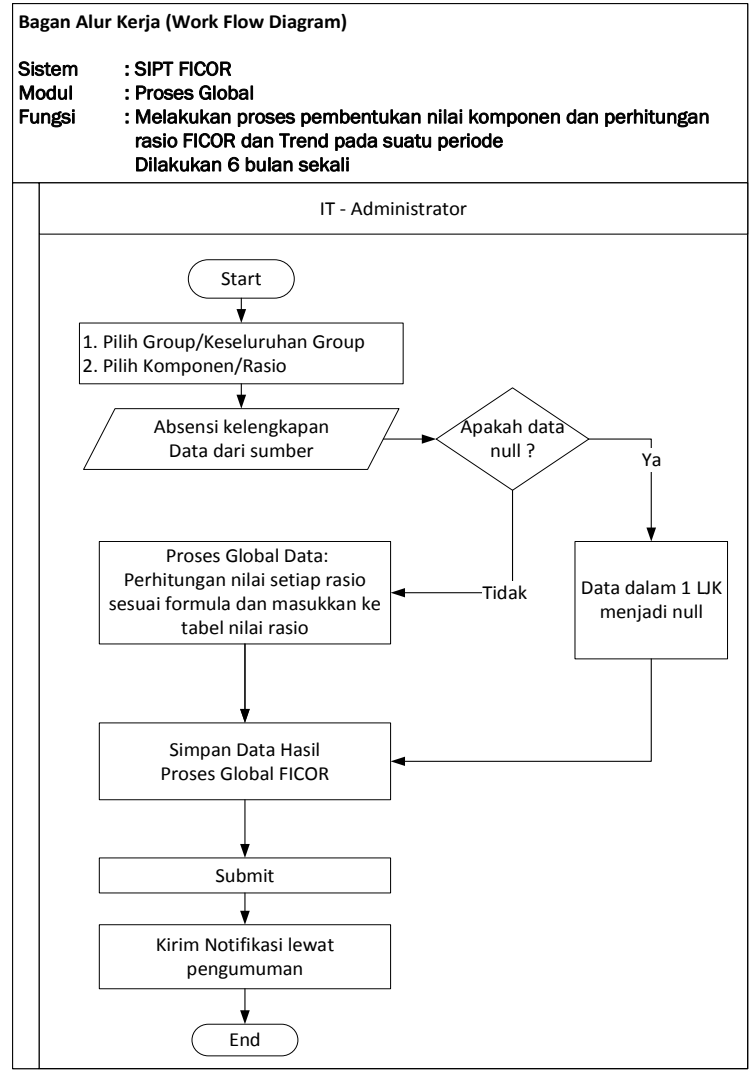

Gambar 9 Bagan Alur Kerja Proses Global

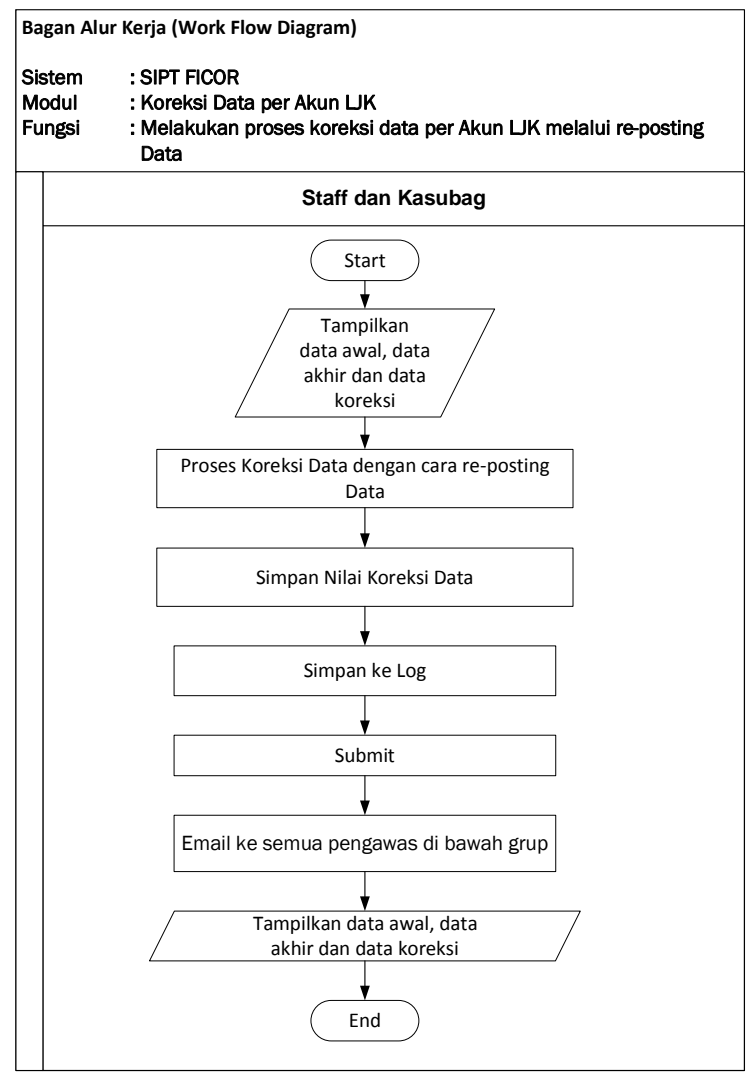

Gambar 10 Bagan Alur Kerja Proses Koreksi Data per Akun LJK 


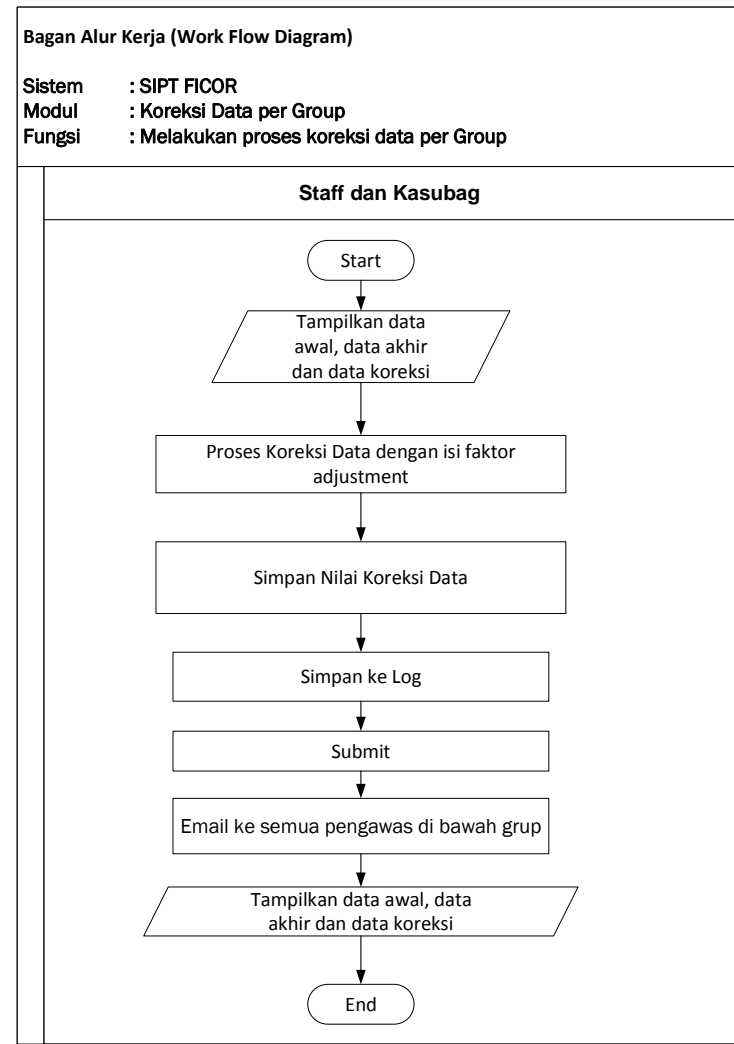

Gambar 11 Bagan Alur Kerja Proses Koreksi Data per Group

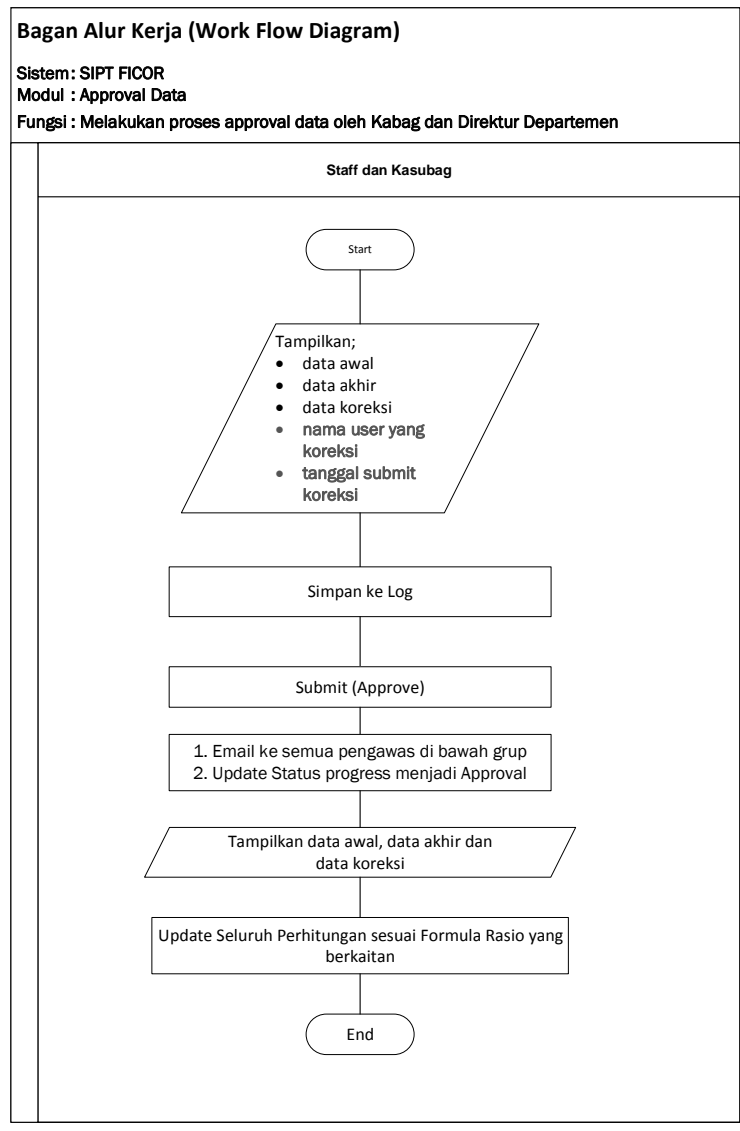

Gambar 12 Bagan Alur Kerja Proses Approval Data

\section{DAFTAR PUSTAKA}

[1] Butler Group. Business Process Management. March 2002.

[2] Dumas, Marlon., La Rosa, Marcello., Mendling, Jan., Reijers, Hajo A. Fundamentals of Business Process Management. Springer, 2013.

[3] Harahap, Sofyan Syafri. Analisis Kritis atas Laporan Keuangan. Raja Grafindo Persada, Jakarta, 2008.

[4] Irawati Susan. Manajemen Keuangan, Pustaka, Bandung, 2005.

[5] Kasmir. Analisis Laporan Keuangan. Rajawali Pers, Jakarta. 2008 .

[6] Otoritas Jasa Keuangan. Peraturan Otoritas Jasa Keuangan No. 17/POJK.O3/2014 tentang Penerapan Manajemen Risiko Terintegrasi Konglomerasi Keuangan, 2013.

[7] Otoritas Jasa Keuangan. Peraturan Otoritas Jasa Keuangan Nomor 18/POJK.03/2014 tentang Penerapan Tata Kelola Terintegrasi Bagi Konglomerasi Keuangan, 2014.

[8] Otoritas Jasa Keuangan. Rancangan Peraturan Otoritas Jasa Keuangan tentang Perusahaan Induk Konglomerasi Keuangan tahun 2017. Jakarta. 2017.

[9] https://finance.detik.com/moneter/3528674/mulai-1januari-2019-konglomerasi-keuangan-harus-punyainduk, diakses pada tanggal 28 Oktober 2017.

[10] http://ekonomi.kompas.com/read/2014/09/26/052800426 /OJK.Galakkan.Pengawasan.terhadap.Konglomerasi.Ke uangan, diakses pada tanggal 28 Oktober 2017.

[11] http://ekonomi.metrotvnews.com/mikro/GNl6QDVkojk-akan-terbitkan-aturan-peraturan-perusahaan-indukkonglomerasi-keuangan, diakses pada tanggal 28 Oktober 2017. 